\title{
FEATURES OF THE CLINICAL COURSE OF ROTAVIRUS INFECTION IN CHILDREN INFECTED WITH HERPES VIRUSES AND THEIR BLOOD INTERLEUKIN REACTIONS
}

\author{
Sliepchenko M.Yu. \\ Kharkiv National Medical University \\ https://doi.org/10.35339/ic.6.2.101-105
}

\begin{abstract}
Background. The widespread prevalence of intestinal infections of rotavirus etiology, the economic damage caused by it and the difficulties of treating patients cause the medical and social significance of this pathology. Along with this, a herpes virus infection and its negative effect on the immune response of the human body is a pressing problem. The purpose of the study is to identify the characteristics of presentation and the course of rotavirus infection in children infected with herpes viruses, and to establish the characteristics of the reaction of interleukins in their blood. Subjects and Methods. 38 children aged one to three years with moderate and severe forms of intestinal infection rotavirus etiology, who received appropriate treatment were examined. The children were divided into two groups: Group 1 included 18 children who did not have a background infection and Group 2 comprised 20 patients with acute rotavirus infection who were infected with herpes viruses. Along with the generally accepted clinical and laboratory examination, the levels of interleukins $1 \beta, 4, \mathrm{TNF} \alpha$ in the blood serum in the time course of the disease were determined by an ELISA method for all children. Results. Assessment of clinical and immunological parameters of rotavirus infection in children showed that infection with viruses of the herpes group contributed to a less severity of symptoms of the disease at the initial stage, but longer persistence, which was probably due to insufficient reaction of proinflammatory interleukins in blood in the acute period at relatively high levels during the course of the disease.

Keywords: clinic, children, cytokines, herpes and rotavirus infections.
\end{abstract}

\section{Introduction}

Intestinal infections (II) are among the most common children diseases $[1,11]$. Their etiological structure is extremely polymorphic. The causative factor of the disease may be protozoa, bacteria, fungi, viruses, etc. $[14,16,20]$. Studies conducted in recent decades proved the leading role of viruses in the development of II [3, 17]. Among them, the dominant role is played by rotaviruses (RV) $[2,3]$. According to WHO statistics, about 125 million cases of rotavirus etiology are observed in the world every year, and over 500

Corresponding Author:

Margarita Sliepchenko, Assistant

of the Department of Pediatric Infectious Diseases of Kharkiv National Medical University, Ukraine.

E-mail:Dr.Margaritasl@gmail.com. thousand children under the age of 5 die from this pathology $[4,5]$.

The clinical picture of lesions of the gastrointestinal tract of rotavirus nature is rather brightly highlighted in the available literature [2, $3,9]$. However, many scientists have recently noted its significant changes $[6,7,12]$. Some authors attribute this to negative ecological state in many countries and the world as a whole, which contributes, firstly, to the change of the virus itself, and secondly, to the formation of immunesuppressive status in contemporary children [1, $18,15]$. Other researchers believe that changes in the clinical symptoms of rotavirus infection (RVI) are due to the additional infection of the child population, in particular, herpes viruses [10, 13, 19]. 
At the same time, there are very few studies on clinical and immunological features of RVI in children infected with the herpes group in the available literature, and their results are very contradictory [8].

Meanwhile, in our opinion, research in this area will reveal the subtle pathogenic mechanisms of rotavirus pathological process in children infected with herpes viruses, which will allow to diagnose background infection in the early stages of the disease and more reasonably and convincingly to approach the treatment of patients.

\section{Purposes, subjects and methods:}

2.1. Purpose: to identify the features of presentation of rotavirus infection in children infected with herpes viruses, as well to establish the features of the reaction of interleukins in their blood.

\subsection{Subjects \& Methods}

The study involved 38 children aged one to three years with moderate and severe forms of intestinal infection of rotavirus etiology, receiving appropriate treatment in Kharkiv Regional Children's Infectious Diseases Hospital. Of these, 18 (the first group) did not have a background infection and 20 (the second group) carried RVI against the background of infection with various herpes viruses. The children of these groups were comparable by sex, age, severity of the disease and other parameters.

RVI was confirmed using the separation of rotavirus antigen from fecal masses of patients by ELISA. The presence of herpes virus infection $(1,2,4,5,6$ types) was proved by the corresponding IgM and IgG classes in the blood (ELISA), or isolation of the virus nucleic acid by Polymerase chain reaction (PCR).

Children with the latent form of the herpes virus infection were included in the study. The latent form of herpes virus infection was established when specific class $\mathrm{G}$ antibodies (IgG) were detected in the titer above the diagnostic one in the absence of other markers (IgM-negative, PCR-negative) and clinical manifestations.

All children were also examined for the presence of other viral or bacterial pathogens causing intestinal infections (feces), patients with a positive result were excluded from the study. Along with the generally accepted clinical and laboratory examination, the levels of interleukins $1 \beta, 4, \mathrm{TNF} \alpha$ in the blood serum in the course of the disease were determined for all children (the acute period is 1-2 days of illness and the recovery period is 6-9 days). The results of the Dr. Kirsanova T.O study (2007) were used as a control [21].
Standard statistics was used for the data analysis.

All research methods were conducted in compliance with legislation on human rights, in accordance with the current legislation of Ukraine and international ethical requirements.

\section{Conflict of interests}

There is no conflict of interests.

\section{Results and discussion}

Analysis of clinical data showed that in both groups of children, the disease mostly began acutely with an increase in body temperature, vomiting and frequent loose stools (Table 1).

The increase in body temperature in children of Group 1 varied on average within $39.11 \pm 0.19^{\circ} \mathrm{C}$, while in Group 2 patients it was $38.44 \pm 0.17^{\circ} \mathrm{C}$ $(p<0.05)$. Catarrhal manifestations in the form of hyperemia of the mucous membrane of the oropharynx and serous discharge from the nose were observed almost equally often in the groups under investigation, which did not contradict the results of the clinical researcher O.V. Usachova (2013) [8]. The number of children not infected with herpes viruses was recorded from one to eight to nine days per day $(6.23 \pm 0.28)$, while in children with background infection it was more often observed one to four times a day $(3,28 \pm 0.39) \mathrm{p}<0.05$.

The stool particles were almost identical in children compared in groups ( $p>0.05)$, although the nature of calories was largely enterocolitic in patients infected with herpes viruses, which, according to some authors, may be due to a weakening of their immune response and systemic actions herpes viruses and, as a result, the involvement in the process of a larger segment of the intestinal tube $[9,10]$.

A comparative analysis of clinical observations showed that children who were not infected with viruses and herpes had more marked temperature reactions, with almost the same severity of catarrhal symptoms and diarrhea syndrome.

Follow-up of children in the time course of the disease showed differences in diseases in groups under comparison (Table 2).

The study showed that in children infected with herpes viruses, the body temperature $(p<0.05)$, intestinal dysfunction $(p<0.05)$ persisted longer, with almost the same, compared with patients not infected with the herpes group, the duration of catarrhal events and vomiting.

Considering the identified differences in the severity of clinical manifestations of RVI at the beginning of the disease and their duration over 
Incidence of the main clinical manifestations of RVI in children

Table 1 of the groups under investigation

\begin{tabular}{|l|c|c|c|c|c|}
\hline \multirow{2}{*}{ Symptoms of RVI } & \multicolumn{2}{c|}{ Group 1 (n=18) } & \multicolumn{2}{c|}{ Group 2 (n=20) } \\
\cline { 2 - 6 } & Abs & $\%$ & Abs & $\%$ \\
\hline \multirow{2}{*}{$\begin{array}{l}\text { Temperature } \\
\text { reaction }\end{array}$} & $37.0-37.9^{\circ} \mathrm{C}$ & 2 & 11.1 & 4 & 20 \\
\cline { 2 - 6 } & $38.0-38.9^{\circ} \mathrm{C}$ & 6 & 33.3 & 13 & 72.2 \\
\cline { 2 - 6 } & $39.0-40.0^{\circ} \mathrm{C}$ & 10 & 55.6 & 3 & 15 \\
\hline \multirow{3}{*}{$\begin{array}{l}\text { Catarrhal } \\
\text { manifestation }\end{array}$} & $\begin{array}{l}\text { Mucous } \\
\text { hyperemia of the } \\
\text { oropharynx }\end{array}$ & 11 & 61.1 & 12 & 60 \\
\cline { 2 - 6 } & $\begin{array}{l}\text { Serous discharge } \\
\text { from the nose }\end{array}$ & 7 & 38.8 & 9 & 45 \\
\hline $\begin{array}{l}\text { Frequency } \\
\text { of vomiting } \\
\text { (per day) }\end{array}$ & No vomiting & 3 & 16.6 & 5 & 25 \\
\cline { 2 - 6 } & $1-4$ & 8 & 44.4 & 12 & 60 \\
\cline { 2 - 6 } $\begin{array}{l}\text { Frequency } \\
\text { of defecation } \\
\text { (a day) }\end{array}$ & 5 or more & 7 & 38.8 & 3 & 15 \\
\cline { 2 - 6 } & $1-4$ & 1 & 5.55 & 2 & 12 \\
\cline { 2 - 6 } & 9 or more & 9 & 50 & 6 & 30 \\
\hline
\end{tabular}

The duration of the main clinical symptoms of RVI

Table 2 in children in the groups under investigation

\begin{tabular}{|l|l|c|c|c|}
\hline \multirow{2}{*}{\multicolumn{2}{|c|}{ Symptoms of RVI }} & \multicolumn{2}{c|}{$\begin{array}{c}\text { The duration } \\
\text { of clinical symptoms (day) }\end{array}$} & $\begin{array}{c}\text { Statistically significant } \\
\text { difference (pt) P }\end{array}$ \\
\cline { 2 - 5 } & $\begin{array}{c}\text { Group 1 (n=18) } \\
\mathrm{M} \pm \mathrm{m}\end{array}$ & $\begin{array}{c}\text { Group 2 }(\mathrm{n}=20) \\
\mathrm{M} \pm \mathrm{m}\end{array}$ & \\
\hline \multicolumn{2}{|l|}{ Temperature reaction } & $3.11 \pm 0.61$ & $4.06 \pm 1.33$ & $\mathrm{p}<0.05$ \\
\hline \multirow{2}{*}{$\begin{array}{l}\text { Catarrhal } \\
\text { manifestation }\end{array}$} & $\begin{array}{l}\text { Mucous hyperemia } \\
\text { of oropharynx }\end{array}$ & $3.71 \pm 1.04$ & $3.07 \pm 0.8$ & $\mathrm{p}>0.05$ \\
\cline { 2 - 5 } & $\begin{array}{l}\text { Serous discharge } \\
\text { from the nose }\end{array}$ & $3.32 \pm 1.06$ & $3.07 \pm 1.04$ & $\mathrm{p}>0.05$ \\
\hline Vomiting & $2.52 \pm 0.08$ & $2.35 \pm 0.05$ & $\mathrm{p}>0.05$ \\
\hline \multicolumn{2}{|l|}{ Intestinal dysfunction } & $4.36 \pm 0.25$ & $6.12 \pm 0.82$ & $\mathrm{p}<0.05$ \\
\hline
\end{tabular}

time, we conducted studies to determine the strength of the interleukin response in children of the groups under comparison (Table 3).

It was found that the severity of the reaction of pro-inflammatory interleukins (IL- $1 \beta$ and TNF$\alpha$,) in children uninfected with herpes viruses was more pronounced at the onset of the disease (IL$1 \beta-62.382 \pm 3.14$; TNF- $\alpha-58.32 \pm 4.61)$ than in children with additional infection (IL-1 $\beta$ $51.11 \pm 2.67$; TNF- $\alpha-481 \pm 2.39) \mathrm{p}<0.05$. At the same time, the strength of the response of interleukin 4 was almost the same ( $p>0.05)$. In our opinion, it is the more significant reaction of proinflammatory interleukins in children without background infection at the onset of the disease that may explain their more pronounced temperature response and probably a greater frequency of vomiting. By the reconvalescence period, the levels of proinflammatory blood interleukins in patients with background infection remained significantly higher than in children not infected with herpes viruses. The latter seems to be a marker of not fully completed pathological process and an argument explaining the prolongation of clinical symptoms, in favor of which higher IL-4 numbers may indicate in the period of early recovery of children who have an additional infection. 
Table 3

The level of blood interleukins in children of different groups during the course of the disease

\begin{tabular}{|c|c|c|c|c|}
\hline $\begin{array}{l}\text { Interleukins } \\
\quad(\mathrm{pg} / \mathrm{ml})\end{array}$ & $\begin{array}{l}\text { Periods } \\
\text { of the disease }\end{array}$ & Group $1(\mathrm{M} \pm \mathrm{m})$ & Group $2(\mathrm{M} \pm \mathrm{m})$ & $\begin{array}{l}\text { Healthy children } \\
\qquad \begin{array}{l}(\mathrm{pg} / \mathrm{ml}) \\
(\mathrm{M} \pm \mathrm{m})\end{array}\end{array}$ \\
\hline \multirow{2}{*}{$1 \beta$} & acute & $62.82 \pm 3.14$ & $51.11 \pm 2.67$ & \multirow{2}{*}{$26.41 \pm 2.31$} \\
\hline & reconvalescence & $28.55 \pm 2.22$ & $40.06 \pm 1.92$ & \\
\hline \multirow{2}{*}{4} & acute & $38.37 \pm 2.15$ & $33.34 \pm 2.48$ & \multirow{2}{*}{$25.24 \pm 2.41$} \\
\hline & reconvalescence & $26.07 \pm 2.63$ & $34.05 \pm 2.35$ & \\
\hline \multirow{2}{*}{ TNF- $\alpha$} & acute & $58.32 \pm 4.61$ & $48.11 \pm 2.39$ & \multirow{2}{*}{$23.88 \pm 2.31$} \\
\hline & reconvalescence & $27.92 \pm 3.98$ & $37.62 \pm 2.18$ & \\
\hline
\end{tabular}

\section{Conclusions}

Thus, in children infected with herpesviruses, RVI in the debut of the disease in terms of the severity of clinical manifestations is inferior to that in children who do not have background infection. However, the duration of their presence is more significant. These features, apparently, are caused by the insufficiently pronounced reaction of proinflammatory interleukins in the blood of children infected with the herpes viruses at the onset of the disease and the preservation of their indicators at a relatively high level during the course of the disease.

\section{References}

1. Baranov Alexandr A., Namazova-Baranova Leyla,...Kostinov Mikhail. (2017). Rotavirus Infection in Children is an Unsolved Problem. Review of Guidelines for Vaccinal Prevention. Pediatric pharmacology, 14(4), 248-257. doi: 10.15690/pf.v14i4.1756)

2. Chernyshova L.I., AP Voloha, \& AV Bondarenko. (2016). Infectious diseases in children. Kyiv. VSV "Medicine".

3. Nyankovskyy S.L. Yatsula M.S., \& Yaskiv VB.(2015). Acute rotavirus diarrhea in children: clinic, diagnosis, treatment. Actual infectology, 3(8), 43-48. Retrieved from: https://cyberleninka.ru/article/n/ ostraya-rotavirusnaya-diareya-u-detey-klinika-diagnostika-lechenie

4. Lezhenko G.O., Usachova O.V., Tarasenko N.V. (2014). Look at the rotavirus infection in children: epimeterology and clan-pathogenetic features. Journal "Actual Infectology" 2 (3), 12-17.

5. Kramarov S.O., Vigovska O.V., \& Markov A.I. (2014). Viral diarrhea in children: clinical manifestations, innovations in the treatment. Journal "Child Health" 7 (58), 49-55.

6. Bekhtereva M.K., Komarova A.M., Uskov A.N. (2017). Rotavirus infection in children in the Russian Federation: problems of diagnosis and therapy tactics in modern conditions. Medical Council №4, 19-23.

7. Ed. C. D. Zeni. (2014). Rotavirus Infections: Epidemiology, Clinical Characteristics and Treatment Options. New York: Nova Science Publishers Inc.

8. Usacheva, O. V., Pakholchuk, T. M., Silin, Ya. A., Matveeva, T. B., Shulga, O. V., Pechugina, V. V., ... Turljun, V. A. (2013). Special features of rotavirus infection in children of early age with cytomegaly and approaches to pathogenetic therapy. Modern Pediatrics, (1), 134-138.

9. Zaytseva L.Yu, Khmelevskaya I.G., Kalutskiy P.V. (2017). Clinical and immunological features of viral diarrhea in children. The Bulletin of Contemporary Clinical Medicine, 10 (2), 30-33.

10. V. V. Krasnov, T. D. Aleksandrova, \& L. V. Nazarova. (2018). The prevalence of herpes virus infections in the active phase in hospitalized children with rotavirus infection. Children's Infections, $17(4), 18-21$.

11. Chhabra P., Payne D.C., ...Vinje J.(2013) Etiology of viral gastroenteritis in children $<5$ years of age in the United States, 2008-2009. The Journal of infectious diseases №?208(5), 790-800.

12) S. Barton, W. White, Douglas and S. Cathelyn, ... W. Virgin.(2007, June). Herpesvirus latency confers symbiotic protection from bacterial infection. Journal Nature V 447, 326-329. doi 10.1038/ nature 05762 .

13) White DW, Suzanne Beard R, Barton ES.(2012). Immune modulation during latent herpesvirus infection. Immunol Rev. 245(1),189-208. doi:10.1111/j.1600-065X.2011.01074.x 
14) Troeger C, Forouzanfar M, Rao PC, Khalil I, Brown A, Reiner RC Jr, Fullman N., ... Mokdad AH. (2017, September). Estimates of the global, regional, and national morbidity, mortality, and aetiologies of diarrhoea in 195 countries: a systematic analysis for the Global Burden of Disease Study 2016. The Lancet Infectious Diseases, 17(9), 909-948. doi: 10.1016/S1473-3099(17)30276-1.

15) Suvi Lappalainen, Samuli Ylitalo, \& Timo Vesikari. (2012, February 01). Simultaneous presence of human herpesvirus 6 and adenovirus infections in intestinal intussusception of young children. Acta Paediatrica, 101(6), 663-670. https://doi.org/10.1111/j.1651-2227.2012.02616.x

16) Guarino A, Ashkenazi Sh, Gendrel D. (2014, July). European Society for Paediatric Gastroenterology, Hepatology, and Nutrition. European Society for Paediatric Infectious Diseases Evidence-based Guidelines for the Management of Acute Gastroenteritis in Children in Europe. JPGN, 59(1), 132-152. doi: 10.1097/ MPG.0000000000000375.

17) Khambhampati A, Payne DC, Constantini V, Lopman BA.(2016). Host genetic susceptibility to enteric viruses: a systematic review and meta-analysis. Clin Infect Dis 62(1),11-8. doi: 10.1093/cid/ civ873.

18) O. V. Shamsheva, F. S. Kharlamova, \& N. A. Guseva.(2017) The Results of Long-term Study of Herpesvirus Infection at the Department of Infectious Diseases in Children of Russian National Research Medical University. Children's Infections, 16(2), 5-12. Retrieved from https://doi.org/10.22627/20728107-2017-16-2-5-12

19) Leena Halme, Johanna Arola, \& Irmeli Lautenschlager (2008, February1). Human Herpesvirus 6 Infection of the Gastroduodenal Mucosa. Clinical Infectious Diseases, 46 (3), 434-439. Retrieved from https://doi.org/10.1086/525264

20) Pfeiffer, J. K., \& Virgin, H. W. (2016, Jan, 15). Viral immunity. Transkingdom control of viral infection and immunity in the mammalian intestine. Science 351(6270). doi:10.1126/science.aad5872

21) Kirsanova T.O., Kuznetsov S.V. (2007). Immune status of children, patients with rotavirus mixtinfections. Annals of Mechnicov Institute (3), 24-27. www.imiamn.org.ua/journal/3_2007/PDF/8.pdf

Received: 29-Mar-2019

Accepted: 12-June-2019 